\title{
Effects of triclosan on growth, viability and fatty acid synthesis of the oyster protozoan parasite Perkinsus marinus
}

\author{
Eric D. Lund ${ }^{1}$, Philippe Soudant ${ }^{2}$, Fu-Lin E. Chu ${ }^{1, *}$, Ellen Harvey ${ }^{1}$, \\ Stephanie Bolton ${ }^{3}$, Adolph Flowers ${ }^{4}$
}

\author{
${ }^{1}$ Virginia Institute of Marine Science, College of William and Mary, Gloucester Point, Virginia 23062, USA \\ ${ }^{2}$ Université de Bretagne Occidentale, Institut Universitaire Européen de la Mer LEMAR-Laboratoire des Sciences de \\ l'Environnement Marin (UMR 6539), Technopole Brest Iroise, Place Nicolas Copernic, 29280 Plouzané, France \\ ${ }^{3}$ Wake Forest University, 1834 Wake Forest Road, Winston-Salem, North Carolina 27106, USA \\ ${ }^{4}$ Morehouse College, 830 Westview Drive SW, Atlanta, Georgia 30314, USA
}

\begin{abstract}
Perkinsus marinus, a protozoan parasite of the Eastern oyster Crassostrea virginica, has severely impacted oyster populations from the Mid-Atlantic region to the Gulf of Mexico coast of North America for more than $30 \mathrm{yr}$. Although a chemotherapeutic treatment to reduce or eliminate $P$. marinus from infected oysters would be useful for research and hatchery operations, an effective and practical drug treatment does not currently exist. In this study, the antimicrobial drug triclosan 5-chloro-2-(2,4 dichlorophenoxy) phenol, a specific inhibitor of Fab1 (enoyl-acyl-carrier-protein reductase), an enzyme in the Type II class of fatty acid synthetases, was tested for its effects on viability, proliferation and fatty acid synthesis of in vitro-cultured $P$. marinus meronts. Treatment of $P$. marinus meront cell cultures with concentrations of $\geq 2 \mu \mathrm{M}$ triclosan at $28^{\circ} \mathrm{C}$ (a temperature favorable for parasite proliferation) for up to $6 \mathrm{~d}$ stopped proliferation of the parasite. Treatment at $\geq 5 \mu \mathrm{M}$ at $28^{\circ} \mathrm{C}$ greatly reduced the viability and fatty acid synthesis of meront cells. Oyster hemocytes treated with $\geq 20 \mu \mathrm{M}$ triclosan exhibited no significant $(\mathrm{p}<0.05)$ reduction in viability relative to controls for up to $24 \mathrm{~h}$ at $13^{\circ} \mathrm{C}$. P. marinus meronts exposed to $\geq 2 \mu \mathrm{M}$ triclosan for $24 \mathrm{~h}$ at $13^{\circ} \mathrm{C}$ exhibited significantly $(\mathrm{p}<0.05)$ lower viability relative to controls. Exposure of $P$. marinus meronts to triclosan concentrations of $\geq 20 \mu \mathrm{M}$ resulted in $>50 \%$ mortality of $P$. marinus cells after $24 \mathrm{~h}$. These results suggest that triclosan may be effective in treating $P$. marinus-infected oysters.
\end{abstract}

KEY WORDS: Triclosan $\cdot$ Dermo disease $\cdot$ Perkinsus marinus $\cdot$ Eastern oyster $\cdot$ Fatty acid synthesis

Resale or republication not permitted without written consent of the publisher

\section{INTRODUCTION}

The protozoan parasite Perkinsus marinus, causative agent of Dermo disease in the Eastern oyster Crassostrea virginica, has decimated oyster populations along the Atlantic coast of North America and the Gulf of Mexico for at least $30 \mathrm{yr}$. One element critical to both the restoration of wild oyster populations and the development of commercial aquaculture operations is a practical method for reducing or eliminating $P$. marinus from infected oysters. Currently, virtually all oysters in the mid-Atlantic region are infected with $P$. marinus (Burreson \& RagoneCalvo 1996), which has severe ramifications for restoration efforts, oyster disease research and commercial oyster aquaculture.

Potential benefits from the development of a protocol to eliminate Perkinsus marinus from infected oysters include (1) increasing the quantity and quality of gametes of oysters conditioned for hatchery spawns; (2) a reduction in the frequency of spawning required to maintain specific strains of oysters; (3) production of disease-free spat; (4) production of disease-free oysters for use in research on host-parasite interactions. 
To be practical for use in controlling Perkinsus marinus infection, a drug therapy needs to have several important features: (1) high specific action against the parasite; (2) low toxicity to the host; (3) application through direct addition to water in holding containers; (4) low/no toxicity to humans; (5) low cost and ready availability. Several studies evaluating potential chemotherapeutic agents for treatment of Dermo disease have been published, but the protocols so far developed to successfully treat $P$. marinus infection in oysters fail to meet several of these criteria (Ray 1966a,b, Calvo \& Burreson 1994, Faisal et al. 1999, Delaney et al. 2003).

Parasitic protozoans must either acquire lipids from their host or synthesize lipids de novo to produce the new cell membrane necessary for cell replication. Inhibiting the ability to synthesize new membrane prevents the parasite from increasing in surface area, thereby halting cell proliferation and disease progression.

The antimicrobial drug triclosan, 5-chloro-2-(2,4 dichlorophenoxy) phenol, has been used in a wide array of consumer products such as soaps, toothpastes and household plastics for the last $30 \mathrm{yr}$. Triclosan inhibits fatty acid synthesis and stops the proliferation of protozoan parasites including species of the genera Plasmodium, Toxoplasma, and Trypanosoma in vitro and in vivo (Beeson et al. 2001, McLeod et al. 2001, Surolia \& Surolia 2001, Roberts et al. 2003). The purpose of the present study was to determine whether triclosan may be a useful chemotherapeutic agent to treat oysters infected with Perkinsus marinus. The effectiveness of triclosan against $P$. marinus was evaluated by measuring the effect of the drug on the growth, viability and fatty acid synthesis of in vitro parasite cultures. To address concerns about potential toxic effect on host cells, the effect of triclosan on oyster hemocyte viability was also assessed.

\section{MATERIALS AND METHODS}

Culture conditions. Perkinsus marinus meront cells were cultivated as previously described (Chu et al. 2002) in medium defined by La Peyre et al. (1993). Medium was prepared with artificial seawater (ASW) and adjusted to an osmolarity of 590 (equivalent to a salinity of 20, Lund et al. 2004). The medium was then sterilized by $0.2 \mu \mathrm{m}$ filtration and stored at $4^{\circ} \mathrm{C}$ until use. Meronts were inoculated at a concentration of $1 \times$ $10^{6} \mathrm{ml}^{-1}$ and cultivated in $10 \mathrm{ml}$ aliquots of medium in $\mathrm{T}-10$ tissue-culture flasks at $28^{\circ} \mathrm{C}$. Meronts in exponential growth phase ( $7 \mathrm{~d}$ old $)$ were harvested and used for all assays.
Expt 1. Effect of triclosan on growth, viability and fatty acid synthesis by Perkinsus marinus. The effects of triclosan on the fatty acid synthesis rates of $P$. marinus were tested by measuring the incorporation of exogenous ${ }^{13} \mathrm{C}$ sodium acetate into fatty acids of P. marinus meront cells. We added $10 \mathrm{ml}$ aliquots of fresh media containing $6 \mathrm{mM}$ sodium acetate $1,2{ }^{13} \mathrm{C}_{2}$ (Cambridge Isotope Laboratories) to culture flasks and inoculated those with $2.5 \times 10^{7}$ cells and $0,2,5$ or $10 \mu \mathrm{M}$ triclosan using ethanol $\left(5 \mu \mathrm{ml}^{-1}\right)$ as a carrier $(\mathrm{n}=3)$. After $72 \mathrm{~h}$ at $28^{\circ} \mathrm{C}$, cultures were harvested and cell density and percentage of viable cells for each culture flask was determined using a neutral red assay (Borenfreund \& Puerner 1985), and fatty acid synthesis rates were determined by gas chromatography/mass spectroscopy (GC/MS) (Chu et al. 2002).

Expt 2. Viability and cell proliferation of Perkinsus marinus cultures exposed to different levels of triclosan. To test a wide range of triclosan concentrations, $21 \mathrm{~T}-10$ tissue-culture flasks containing $10 \mathrm{ml}$ aliquots of medium were inoculated with $1 \mathrm{ml}(0.25 \times$ $10^{6}$ cells) of $4 \mathrm{~d}$ old $P$. marinus culture. Triclosan solutions of $0,2,5,10,20,50$ and $100 \mu \mathrm{M}$ were added with ethanol $\left(5 \mu \mathrm{ml}^{-1}\right)$ to the culture flasks (3 replicates per treatment). Aliquots of $1.2 \mathrm{ml}$ from each culture flask were collected after 3 h, 24 h, 3 d and 6 d incubation at $28^{\circ} \mathrm{C}$ for determination of cell culture density and viability measurements by flow cytometry (FCM). All the suspensions were filtered through $80 \mu \mathrm{m}$ mesh into FCM tubes and maintained on ice until FCM analysis.

Expt 3. Viability of oyster hemocytes exposed to triclosan. Adult oysters, Crassostrea virginica, were supplied by Pemaquid Oyster Company (Waldoboro) and maintained in a flow-through seawater system at ambient temperature $\left(13\right.$ to $\left.14^{\circ} \mathrm{C}\right)$ and salinity (15 to 20). They were processed as follows: hemolymph was withdrawn from the adductor muscle through a notch previously $(24 \mathrm{~h})$ ground in the oyster shell, using a $1 \mathrm{ml}$ plastic syringe with a 25-gauge needle. Hemolymph from each oyster was transferred into an individual Eppendorf tube held on ice. Only individual samples confirmed by microscope observation to be free of contaminating particles were used. Hemolymph from 30 individuals was pooled to constitute 3 replicates of $9 \mathrm{ml}$ of fresh hemolymph. Pooled hemolymph samples were filtered through $80 \mu \mathrm{m}$ mesh prior to use. We combined $1 \mathrm{ml}$ of hemolymph with $1 \mathrm{ml}$ of antiaggregant hemocyte solution (AAHS, Auffret \& Oubella 1995) in 21 Falcon vials ( 7 vials per hemolymph pool), and then added 0, 2, 5, 10, 20, 50 and $100 \mu \mathrm{M}$ of the ethanol $\left(5 \mu \mathrm{l} \mathrm{ml}^{-1}\right)$ triclosan solutions to the $2 \mathrm{ml}$ hemolymph + AAHS mix (3 replicates per ttreatment). The hemolymph was continuously maintained on ice until initiation of incubation. All the Falcon tubes were thus incubated at $13^{\circ} \mathrm{C}$ (the temper- 
ature at which, the oyster were maintained prior to bleeding). After $24 \mathrm{~h}$ incubation, $0.6 \mathrm{ml}$ of each cell suspension was collected and filtered into FCM tubes for subsequent FCM analysis.

Expt 4. Viability of Perkinsus marinus meronts exposed to triclosan at temperature similar to that in oyster hemocyte challenge. To compare triclosan treatment of Perkinsus marinus meronts with oyster hemocytes, meronts were cultured at $13^{\circ} \mathrm{C}$ for 2 wk prior to triclosan challenge. Cultures were concentrated by centrifugation at $800 \times g$ for $20 \mathrm{~min}$, and then used to inoculate $5 \mathrm{ml}$ of fresh medium into each flask to a final concentration of $10^{6}$ cells $\mathrm{ml}^{-1}$. Cultures were exposed to $0,2,5,10,20,50$ and $100 \mu \mathrm{M}$ triclosan at $13^{\circ} \mathrm{C}$ using ethanol $\left(5 \mu \mathrm{ml}^{-1}\right)$ as a carrier $(\mathrm{n}=3)$. The number of viable meronts after $24 \mathrm{~h}$ was determined using a neutral red viability assay (Borenfreund \& Puerner 1985). The percentage of viable cells was determined by dividing the number of viable cells in a treatment by the number of viable cells in controls (0 $\mu \mathrm{M}$ triclosan).

Measurement of Perkinsus marinus fatty acid synthesis rates by GC/MS. Fatty acid synthesis rates as measured by ${ }^{13} \mathrm{C}$ incorporation into meront fatty acids were determined as described previously (Chu et al. 2002). Briefly, cell pellets were freeze-dried and lipids extracted according to the method of Bligh \& Dyer (1959). An aliquot of approximately $500 \mu \mathrm{g}$ of lipids from each sample and $20 \mu \mathrm{g}$ internal standard (23:0) were transesterified by addition of $1 \mathrm{ml}$ of $10 \% \mathrm{BF}_{3}$ (w/w) in methanol followed by heating for $15 \mathrm{~min}$ at 95 to $100^{\circ} \mathrm{C}$ (Metcalfe \& Schmitz 1961). After cooling, the fatty acid methyl esters (FAME) were extracted with carbon disulfide (Marty et al. 1992). The organic phase was evaporated, and the samples dissolved in hexane.

Separation of FAME was carried out on a GC/FID (gas chromatograph equipped with a flame ionization detector) (Varian 3300), using a DBWAX capillary column ( $\mathrm{J} \& \mathrm{~W}, 25 \mathrm{~m} \times 0.32 \mathrm{~mm}$; $0.2 \mu \mathrm{m}$ film thickness). The column temperature was programed from 60 to $150^{\circ} \mathrm{C}$ at $30^{\circ} \mathrm{C} \mathrm{min}-1$ and 150 to $220^{\circ} \mathrm{C}$ at $2^{\circ} \mathrm{C} \mathrm{min}{ }^{-1}$, injector and detector temperatures were 230 and $250^{\circ} \mathrm{C}$, respectively, and the flow rates of compressed air and hydrogen were 300 and $30 \mathrm{ml} \mathrm{min}^{-1}$. Helium was used as the carrier gas $\left(2 \mathrm{ml} \mathrm{min}{ }^{-1}\right)$. Identification of FAMEs was based on the comparison of their retention times with those of authentic standards and confirmed by GC/MS. The quantity of each component was calculated based on the internal standard.

To detect incorporation of ${ }^{13} \mathrm{C}$ acetate, FAMEs were further analyzed qualitatively and quantitatively by mass spectroscopy with a Varian 3400 gas chromatograph equipped with a Varian Saturn 4D GC/MS/MS detector. Methane was used as the reagent gas for positive chemical ionization (CI). The same column as that used for GC/FID analysis of the FAME samples (J \& W DB-WAX, $25 \mathrm{~m} \times 0.32 \mathrm{~mm}$; $0.2 \mu \mathrm{m}$ film thickness) was used for GC/MS analysis. Carrier gas (helium) flow rate was $1 \mathrm{ml} \mathrm{min}{ }^{-1}$. The temperature of the injection port was $230^{\circ} \mathrm{C}$ and that of the interface $250^{\circ} \mathrm{C}$. The column temperature was programed for a 4 min hold at an initial temperature of $60^{\circ} \mathrm{C}$, followed by a $30^{\circ} \mathrm{C} \mathrm{min}{ }^{-1}$ increase to $150^{\circ} \mathrm{C}$ and a subsequent $2^{\circ} \mathrm{C} \min ^{-1}$ increase to $220^{\circ} \mathrm{C}$. Data were collected and processed using Varian Saturn GC/MS software Version 5.2. FAMEs were identified by retention time relative to known standards, fragmentation pattern and mass of the molecular ion. FAMEs containing ${ }^{13} \mathrm{C}$ derived from acetate were quantified using standard curves constructed for each FAME standard and ratio with an internal standard (23:0). The molecular ions in the spectra of each FAME were used to quantify masses containing exogenous ${ }^{13} \mathrm{C}$ relative to the native molecule. Samples from cultures containing unlabeled sodium acetate were also analyzed in an identical manner, and served as negative controls for ${ }^{13} \mathrm{C}$ incorporation. Data were expressed as micrograms of fatty acids containing stable isotope $\mathrm{g}^{-1}$ dry cell pellet $\mathrm{h}^{-1}$.

Determination of cell concentration and viability by flow cytometry. FCM analysis of Perkinsus marinus meronts and Crassostrea virginica hemocyte viability were carried out using a Coulter ${ }^{\circledR}$, EPICS $^{\circledR}$, Altra $^{\mathrm{TM}}$ flow cytometer. Briefly, cells were stained with 2 nucleic acid fluorescent dyes: the permeant SYBR Green I (excitation $=497 \mathrm{~nm}$, emission $=520 \mathrm{~nm}$, commercial stock solution at $10000 \times$, molecular probes, S-7563) and the impermeant propidium iodide, PI, (excitation = $535 \mathrm{~nm}$, emission $=617 \mathrm{~nm}$, Sigma, P4170) at the respective final concentrations of $1 \times$ of stock solution (10 000×) and $10 \mu \mathrm{g} \mathrm{ml}^{-1}$. SYBR Green I stains both live and dead cells and PI stains only cells that have lost membrane integrity (dead cells). The principle of this assay is that SYBR Green I fluorescence (FL1) differentiates live and dead cells from other particles (e.g. cell debris) present in the medium and from instrument 'noise', while PI allows detection of dead cells on the FL3 detector. Samples were incubated with the dyes for $15 \mathrm{~min}$ at room temperature prior to analysis. A data acquisition time of $30 \mathrm{~s}$ was sufficient to obtain between 2000 and 10000 analyzed cells. Data acquisition was in logarithmic mode (4 decades). To calculate $P$. marinus meront cell concentration, the flow rate of the instrument was measured using a known concentration of $10 \mu \mathrm{m}$ diameter fluorescent microspheres (Coulter PN6605359).

Treatment of the FCM data was performed with the software WinMDI Version 2.8 (Joseph Trotter ${ }^{\circledR}$ ). Perkinsus marinus meronts and oyster hemocytes were first identified and selected according to 3 FCM para- 
meters: forward scatter (FSC), side scatter (SSC) and yellow-green fluorescence (FL1). FSC corresponds to the diffracted light on the small angle (detected in line with the incident light source) and is proportional to size. SSC corresponds to the diffracted light on the right angle and is proportional to the cell complexity or granular content. FL1 allowed visualization of the SYBRgreen fluorescence of live and dead cells. After selection, red fluorescence allowed visualization of the PI fluorescence of the dead cells and calculation of the percentage of viable cells in the sample.

Statistical analysis. Analysis of variance (ANOVA) was used to compare the differences in proliferation and fatty acid synthesis rates for Perkinsus marinus meronts exposed to different concentrations of triclosan (Expt 1) and FCM measurements of cell concentration of $P$. marinus meronts exposed to different concentrations of triclosan for $3 \mathrm{~h}, 24 \mathrm{~h}, 3 \mathrm{~d}$ and $6 \mathrm{~d}$ (Expt 2). When significant $(\mathrm{p}<0.05)$ treatment effects were found, individual comparisons were conducted using Tukey's Honestly Significant Difference (HSD) test.

Differences between percentage of viable Crassostrea virginica hemocytes (Expt 3) and Perkinsus marinus meronts (Expt 4) exposed to different concentrations of triclosan for $24 \mathrm{~h}$ (Expt 3) at $13^{\circ} \mathrm{C}$ were determined using ANOVA. When significant $(p<0.05)$ treatment effects were found, individual comparisons were conducted using Tukey's HSD test. All percentage data were arcsine-transformed prior to statistical analysis. Differences were considered significant when $\mathrm{p}<0.05$.

\section{RESULTS}

\section{Expt 1}

Perkinsus marinus cell cultures incubated with 5 and $10 \mu \mathrm{M}$ triclosan exhibited lower cell densities and lower cell viability than controls (Table 1). The $2 \mu \mathrm{M}$ triclosan treatment produced a similar trend, but cell density and viability were not significantly lower than in the controls. After $3 \mathrm{~d}$ incubation, the control cultures had increased from an initial concentration of $2.5 \times 10^{6}$ cells ml $^{-1}$ to $12.7 \pm 0.9 \times 10^{6}$ cells ml $^{-1}$ while the 2, 5 and $10 \mu \mathrm{M}$ triclosan treatments had cell densities of $10.2 \pm 0.6,7.7 \pm 1.7$ and $1.0 \pm 0.2 \times 10^{6}$ cells $\mathrm{ml}^{-1}$, respectively (Table 1 ). Cell viability was also significantly $(\mathrm{p}<0.05)$ lower in the 5 and $10 \mu \mathrm{M}$ treat- ments relative to the controls and $2 \mu \mathrm{M}$ treatment (Table 1).

Incorporation of ${ }^{13} \mathrm{C}$ from acetate into the initial product of fatty acid synthesis, palmitic acid (16:0) (Table 1), was significantly reduced in all triclosan treatments relative to the controls. Controls had a synthesis rate for palmitic acid of $70.7 \pm 6.1 \mu \mathrm{g} \mathrm{g}^{-1}$ dry wt $\mathrm{h}^{-1}$, which was significantly higher than that of the 2,5 and $10 \mathrm{mM}$ triclosan treatments $(55.0 \pm 2.4,14.3 \pm 1.7$ and $8.6 \pm 2.1 \mu^{-1} g^{-1}$ dry wt $h^{-1}$, respectively) (Table 1). Synthesis of 20:4(n-6) (arachidonic acid), an important prostaglandin precursor, was also significantly inhibited in all triclosan treatments relative to the controls (Table 1).

\section{Expt 2}

Proliferation rates of Perkinsus marinus cultures were inhibited by increasing dosages of triclosan relative to the controls (Fig. 1). At $3 \mathrm{~h}$ post-inoculation the control already had the highest cell density $(1.48 \pm 0.68$ $\times 10^{5}$ cells $\mathrm{ml}^{-1}$ ), but was only significantly higher than the 5 and $10 \mu \mathrm{M}$ treatments $(1.08 \pm 0.05$ and $1.13 \pm$ $0.11 \times 10^{5}$ cells ml $^{-1}$, respectively) (Fig. $1 \mathrm{~A}$ ). From $24 \mathrm{~h}$ on through the $6 \mathrm{~d}$ experiment, no treatment above $2 \mu \mathrm{M}$ had a cell density higher than $1.3 \times 10^{5}$ cells ml $^{-1}$ (Fig. 1B-D). In contrast, the control treatment increased from the initial inoculation density of $1 \times$ $10^{5}$ cells ml ${ }^{-1}$ to $2.32 \pm 0.22 \times 10^{5}$ cells ml $\mathrm{m}^{-1}$ at $24 \mathrm{~h}$, $19.31 \pm 1.09 \times 10^{5}$ cells ml ${ }^{-1}$ at $3 \mathrm{~d}$, and $37.40 \pm 4.60 \times$ $10^{5}$ cells ml $\mathrm{ml}^{-1}$ at $6 \mathrm{~d}$ (Figs. 1B-D). These values were significantly higher $(p<0.05)$ than in any of the triclosan treatments. The culture in the $2 \mu \mathrm{M}$ treatment proliferated slightly during the course of the experiment, increasing to $1.67 \pm 0.08,3.76 \pm 0.15$ and $3.69 \pm$ $0.61 \times 10^{5}$ cells ml $\mathrm{m}^{-1}$ at $24 \mathrm{~h}, 3 \mathrm{~d}$ and $6 \mathrm{~d}$, respectively, but growth was significantly attenuated relative to the controls (Fig. 1B-D). 

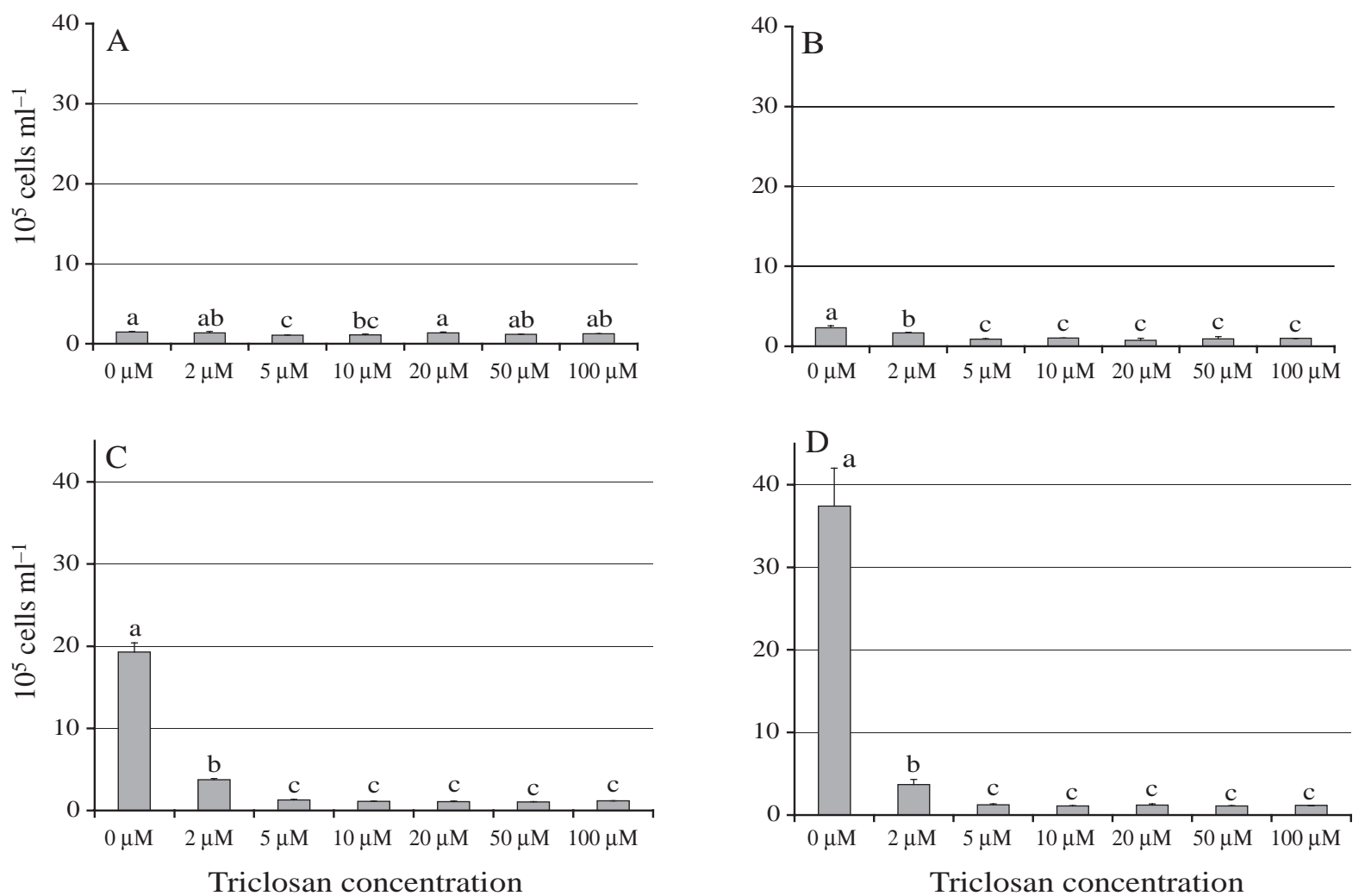

Fig. 1. Perkinsus marinus. Proliferation of in vitro cultures exposed to triclosan for (A) $3 \mathrm{~h}$, (B) $24 \mathrm{~h}$, (C) $3 \mathrm{~d}$, (D) $6 \mathrm{~d}$ measured by flow cytometry using SYBR Green I/propridium iodide labeling $(\mathrm{n}=3)$. Different letters indicate significant differences at the $\mathrm{p}<0.05$ level

\section{Expt 3}

Oyster hemocytes treated with triclosan exhibited mortalities of less than $10 \%$ at triclosan concentrations of $<20 \mu \mathrm{M}$ for up to $24 \mathrm{~h}$ (Fig. 2). No significant ( $\mathrm{p}<$ $0.05)$ reduction in viability relative to the controls occurred at triclosan concentrations below $50 \mu \mathrm{M}$.

\section{Expt 4}

After $24 \mathrm{~h}$ triclosan exposure at $13^{\circ} \mathrm{C}$, all Perkinsus marinus treatments exhibited significantly $(\mathrm{p}<0.05)$ lower viability relative to the controls (Fig. 3). Incubation at triclosan concentrations $\geq 20 \mu \mathrm{M}$ resulted in $>50 \%$ mortality of $P$. marinus cells, and incubations at concentrations of $\geq 50 \mu \mathrm{M}$ in almost $100 \%$ mortality after $24 \mathrm{~h}$.

\section{DISCUSSION}

The results of the current study are very encouraging, since triclosan has been shown to inhibit proliferation of Perkinsus marinus in vitro at $28^{\circ} \mathrm{C}$ (a tem- perature that favors parasite proliferation) at concentrations as low as 2 to $5 \mu \mathrm{M}$ (Table 1, Fig. 1), and to reduce cell viability at concentrations as low as $5 \mu \mathrm{M}$ at both 28 and $13^{\circ} \mathrm{C}$ (Table 1, Fig. 2). In contrast, oyster hemocytes exhibited less than $20 \%$ mortality after $24 \mathrm{~h}$ exposure to triclosan concentrations below $50 \mu \mathrm{M}$ at

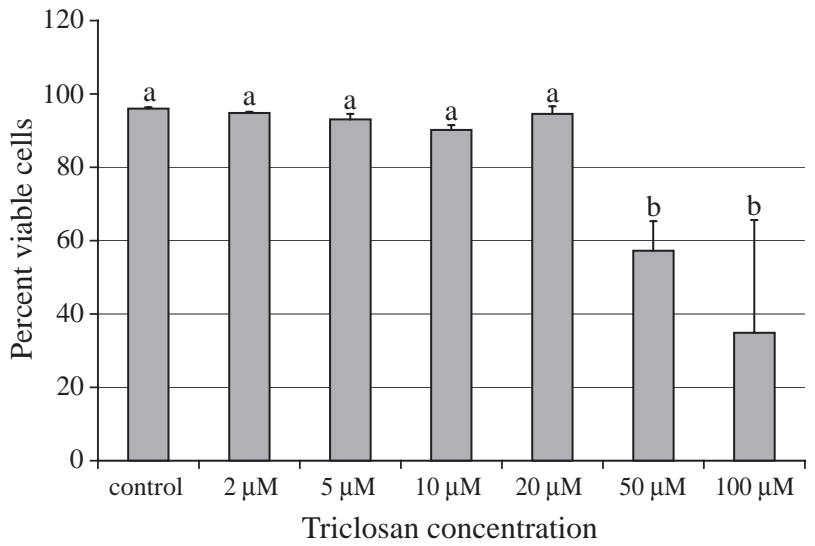

Fig. 2. Crassostrea virginica. Viability of in vitro-cultured oyster hemocytes exposed to triclosan for $24 \mathrm{~h}$ at $13^{\circ} \mathrm{C}(\mathrm{n}=3)$. Viability of hemocytes was determined using SYBR Green I/propridium iodide labeling. Different letters indicate significant differences in viability of treatments at the $p<0.05$ level 


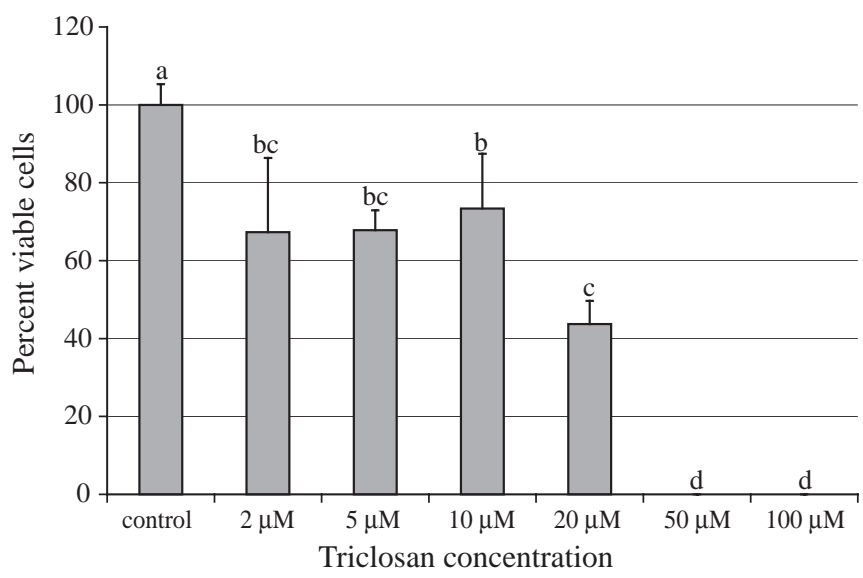

Fig. 3. Perkinsus marinus. Viability of in vitro-cultured meronts exposed to triclosan for $24 \mathrm{~h}$ at $13^{\circ} \mathrm{C}(\mathrm{n}=3)$. Viability of cultures determined using neutral red assay. Different letters indicate significant differences in viability of treatments at the $p<0.05$ level

$13^{\circ} \mathrm{C}$ (Fig. 2). This suggests that it may be possible to treat $P$. marinus-infected oysters with a concentration of triclosan that will kill the parasite without substantially harming the host oyster. To the best of our knowledge, no studies have yet been conducted on the toxicity of triclosan to any molluscan species. However, the $48 \mathrm{~h}$ $\mathrm{EC}_{50}$ of triclosan for Ceriodaphnia dubia has been determined to be $400 \mu \mathrm{g} \mathrm{l}^{-1}$, and triclosan can significantly reduce survival of rainbow trout fry at a concentration of $71 \mathrm{\mu g} \mathrm{l}^{-1}$ (Orvos et al. 2002). As both these levels are below those tested in the current study $(1.5$ to $75 \mathrm{mg}$ $\left.\mathrm{l}^{-1}\right)$, long-term treatment may be potentially harmful to oysters. However, the high survival rate of oyster hemocytes exposed to triclosan for $24 \mathrm{~h}$ suggests that this drug may prove effective in treating this disease.

Although the results of Expts 1 and 2 revealed a similar pattern of decreasing cell proliferation and viability with increasing triclosan concentration, the threshold concentration for effective repression of Perkinsus marinus proliferation appeared to vary between the 2 experiments. In Expt 1, after $3 d$, cell concentration and viability in the $2 \mu \mathrm{M}$ treatment did not differ significantly from control values, and cell concentrations in the $5 \mu \mathrm{M}$ treatment were still above inoculum level (Table 1). Only at $10 \mu \mathrm{M}$ was proliferation completely inhibited (Table 1). In contrast, at Day 3 in Expt 2, all treatments with triclosan concentrations of $5 \mu \mathrm{M}$ were equally effective in suppressing cell proliferation (Fig. 1). These apparent discrepancies may be the result of the lack of synchronicity of the $P$. marinus cultures used in the experiments and/or the different techniques used to measure cell concentrations in Expts 1 and 2. Since the goal of this study was to generate in vitro information for design of in vivo experiments using infected oysters, small inter- experiment variation in the effective minimum concentration does not diminish the significance of the results.

The attenuated activity of triclosan against Perkinsus marinus at $13^{\circ} \mathrm{C}$ (Fig. 3) relative to its activity at $28^{\circ} \mathrm{C}$ may be a function of either lower metabolic activity, or lower drug solubility at colder temperatures. While it may have been preferable, from the perspective of experimental design, to conduct the hemocyte assays in Expt 3 at $28^{\circ} \mathrm{C}$, practical issues precluded this. The oysters used for this study had been procured from a cold-water environment and maintained at ambient water temperatures during the winter. Also, it is doubtful that the hemocytes could have been maintained in vitro for $24 \mathrm{~h}$ at elevated temperatures. Phagocytic activity of oyster hemocytes is reduced at temperatures $>25^{\circ} \mathrm{C}$ (Chu \& LaPeyre 1993). The greater tolerance of oyster hemocytes at $13^{\circ} \mathrm{C}$ relative to the level of triclosan tolerance of the parasite (Figs. $2 \& 3$ ) is encouraging and will stimulate further investigations at higher temperatures.

Previously, several studies have tested different chemotherapeutic agents for treatment of Dermo disease. Ray (1966a) tested 12 fungicides against Perkinsus marinus in infected oyster tissue by measuring chemotherapeutic inhibition of parasite enlargement in fluid thioglycolate medium (FTM). The most promising drug, cycloheximide, completely inhibited enlargement of $P$. marinus in FTM at concentrations between 0.25 and $1.0 \mu \mathrm{g} \mathrm{ml}^{-1}$. Subsequent testing of cycloheximide on $P$. marinus-infected oysters demonstrated suppression of $P$. marinus proliferation in oysters at dosages of 1 to $50 \mu \mathrm{g} \mathrm{ml} \mathrm{m}^{-1} \mathrm{wk}^{-1}$ and complete elimination of the parasite from infected oysters at $50 \mu \mathrm{g} \mathrm{ml} \mathrm{m}^{-1} \mathrm{wk}^{-1}$ after $164 \mathrm{~d}$ (Ray 1966b). Calvo \& Burreson (1994) screened 8 antifungal antibiotics, including cycloheximide, both in vitro with FTM and with $P$. marinus-infected oysters. Among the drugs tested, only treatment with cycloheximide $\left(10 \mu \mathrm{g} \mathrm{ml}^{-1}\right)$ reduced parasite prevalence. Unfortunately, cycloheximide is now classified by the US Environmental Protection Agency as a suspected mutagen, making it unsuitable for use in treating $P$. marinus-infected oysters.

Faisal et al. (1999) were able to kill Perkinsus marinus in vitro and in vivo using Bacitracin. However, they encapsulated the Bacitracin in liposomes for drug delivery to the oysters, and a very high dosage of the drug (10 $\mathrm{mg} \mathrm{ml}^{-1}$ ) was required to be effective. Since liposomes are time-consuming to prepare and have a useful shelf-life of only a few days, this methodology may not be practical for use in hatchery or aquaculture operations. Furthermore, the large quantities of Bacitracin that would be required to treat hundreds or thousands of oysters would make the procedure prohibitively expensive. 
Delaney et al. (2003) tested the effects of 2 N-halamine compounds, 1,3-dichloro-2,2,5,5-tetramethyl-4imidaolidinone (DC) and 1-chloro-2,2,5,5-tetramethyl-4-imidazolidinone (MC) on the viability of Perkinsus marinus cells in seawater. These compounds apparently damage the outer membrane of $P$. marinus cells, thereby inhibiting osmoregulation. DC induced $100 \%$ mortality of in vitro-cultured $P$. marinus cells after exposure to $44.6 \mathrm{mg} \mathrm{l}^{-1}$ for $8 \mathrm{~h}$, while $\mathrm{MC}$ induced $98.6 \%$ mortality after $8 \mathrm{~h}$ exposure.

Most recently, Elandalloussi et al. (2005) tested the effects of 9 drugs on the viability of Perkinsus olseni, a parasite of the clam Ruditapes decussatus, in vitro and in vivo. Of the drugs tested, only deferoxamine (DFO), an iron chelator, was effective in reducing, but not eliminating, $P$. olseni infection levels in clams when applied at a concentration of $1 \mathrm{mg} \mathrm{l}^{-1}$ or higher. The effects of DFO on P. marinus and Crassostrea virginica are not known, although this would appear to be a promising drug therapy for Dermo disease worthy of further pursuit.

While the results of these previous studies are encouraging, the effective dosage levels of drugs in all these studies, with the exception of Elandalloussi et al.'s (2005) study, were considerably higher than those effective for triclosan. For comparison purposes, the 5, 10 and $20 \mu \mathrm{M}$ triclosan concentrations used in the present study equate to $1.5,3$ and $6 \mu \mathrm{g} \mathrm{ml}^{-1}$, respectively. These are $>1000$-fold lower than the lowest effective concentration of Bacitracin $\left(10 \mathrm{mg} \mathrm{ml}^{-1}\right)$ reported by Faisal et al. (1999), and 1 order of magnitude lower than the effective dosages of the N-halamine compounds tested by Delaney et al. (2003). None of the drugs tested by Calvo \& Burreson (1994) were effective against Perkinsus marinus at concentrations $<10 \mathrm{mg}$ $\mathrm{l}^{-1}$. Furthermore, none of the previous studies, except that of Elandalloussi et al. (2005), tested whether the applied chemicals and dosages have toxic side-effects on the host cells.

Enzymes involved in the acquisition and synthesis of lipids in parasitic protozoans are particularly attractive drug targets. Several of the pathways used for lipid synthesis and acquisition by protozoan parasites differ from those utilized by their hosts (Coombs \& Mueller 2002). For example, animals and some fungi use Type I fatty acid synthetase enzymes for fatty acid synthesis, while bacteria and plants employ Type II fatty acid synthetase enzymes. The Type I class differs from the Type II class in that the former comprise a single multienzyme complex, whereas the latter function as separate enzymes. This affords the potential of creating drugs that specifically target the parasite with minimal impact on the host.

Triclosan offers a high degree of pathogen-specificity because animals use the Type I class of fatty acid syn- thetase enzymes for fatty acid synthesis. Recent studies on triclosan have shown that the drug is a specific inhibitor of Fab1 (enoyl-acyl-carrier-protein reductase), an enzyme in the Type II class of fatty acid synthetases that are found in bacteria and plants, but not animals (Heath et al. 1998, Suguna et al. 2001, Perozzo et al. 2002). This property makes triclosan a potentially attractive chemotherapeutic agent that can kill pathogens that utilize Type II fatty acid synthetase enzymes without harming the host animal. Perkinsus marinus is unique among well-studied parasitic protozoans in that it synthesizes a wide range of polyunsaturated fatty acids (Chu et al. 2002). Some metabolites of these de novo-produced fatty acids apparently contribute to the virulence of this parasite. Its ability for de novo fatty acid synthesis and its morphological characteristic (the presence of a non-photosynthetic plastid in the biflagellate zoospore stage) suggest that this parasite uses Type II class synthetases (Soudant \& Chu 2001, Chu et al. 2002). The finding that triclosan inhibits fatty acid synthesis by $P$. marinus at concentrations as low as $5 \mu \mathrm{M}$ is consistent with the presence of a Type II fatty acid synthetase system in this parasite. Although the genus Perkinsus has been assigned to the phylum Apicomplexa (Levine 1988), recent genetic analysis and reexamination of the ultrastructure of the parasite suggest that its phylogenetic position is closer to the dinoflagellates than to apicomplexans (Fong et al. 1993, Flores et al. 1996, Reece et al. 1997, Siddall et al. 1997, Leander \& Keeling 2004). Several recent studies have shown that the Type II fatty acid synthetases are also found in some protozoan parasites, including the apicomplexans Plasmodium falciparum, Toxoplasma gondii and Trypanosoma sp. (Waller et al. 1998, Kapoor et al. 2001, McLeod et al. 2001, Suguna et al. 2001, Surolia \& Surolia 2001, Roberts et al. 2003). Triclosan has been demonstrated to inhibit both fatty acid synthesis and the proliferation of these parasites in vitro and in vivo (Beeson et al. 2001, McLeod et al. 2001, Surolia \& Surolia 2001). Similarly, the present study has demonstrated that $P$. marius meront cells fail to proliferate at triclosan concentrations at or above $5 \mu \mathrm{M}$.

In summary, triclosan inhibits growth and greatly reduces cell viability of in vitro-cultured Perkinsus marinus. These effects are consistent with a mode of action in which triclosan acts as an inhibitor of Type II fatty acid synthetase which has been demonstrated in bacteria and several Apicomplexan protists (Heath et al. 1998, Kapoor et al. 2001, McLeod et al. 2001, Suguna et al. 2001, Surolia \& Surolia 2001, Perozzo et al. 2002). The observation that triclosan kills $P$. marinus at low (5 to $20 \mu \mathrm{M}$ ) concentrations that have minimal effect on oyster hemocyte viability suggests that this drug may be useful in treating infected oysters. Further toxicology studies with infected and uninfected 
oysters are required to ultimately determine the utility of using triclosan to treat Dermo infections in hatchery and research environs.

Acknowledgements. This study was supported by a grant from the Metabolic Biochemistry Program, Molecular and Cellular Bioscience Division, National Science Foundation (MCB-0131108). We thank Georgeta Constantin and Helen Quinby for technical assistance. Contribution number 2684 of the Virginia Institute of Marine Science, College of William and Mary.

\section{LITERATURE CITED}

Auffret M, Oubella R (1995) Cytological and cytometric analysis of bivalve mollusc hemocytes. In: Stolen JS, Fletcher TC, Smith SA, Zelikoff JT, Kaattari SL, Anderson K, Söderhäll RS, Weeks-Perkins BA (eds) Techniques in fish immunology. SOS Publications, Fair Haven, NJ, p 55-64

Beeson JG, Winstanley PA, McFadden GI, Brown GV (2001) New agents to combat malaria. Nat Med 7:149-150

Bligh EG, Dyer WJ (1959) A rapid method of total lipid extraction and purification. Can J Biochem Physiol 37:911-917

Borenfreund E, Puerner JA (1985) A simple quantitative procedure using monolayer cultures for cytotoxicity assays (HTD/NR-90). J Tissue Cult Methods 9:7-10

Burreson EM, Ragone-Calvo LM (1996) Epizootiology of Perkinsus marinus disease of oysters in Chesapeake Bay, with emphasis on data since 1985. J Shellfish Res 15:17-34

Calvo GW, Burreson EM (1994) In vitro and in vivo effects of eight chemotherapeutants on the oyster parasite Perkinsus marinus (Mackin, Owen, and Collier). J Shellfish Res 13:101-107

Chu FLE, LaPeyre J (1993) Perkinsus marinus susceptibility and defense-related activities in eastern oysters Crassostrea virginica: temperature effects. Dis Aquat Org 16:223-234

Chu FLE, Lund ED, Soudant P, Harvey E (2002) De novo arachidonic acid synthesis in Perkinsus marinus, a protozoan parasite of the eastern oyster Crassostrea virginica. Mol Biochem Parasitol 119:179-190

Coombs GH, Mueller S (2002) Recent advances in the search for new anti-coccidial drugs. Int J Parasitol 32:497-508

Delaney MA, Brady YJ, Worley SD, Huels KL (2003) The effectiveness of $\mathrm{N}$-halamine disinfectant compounds on Perkinsus marinus, a parasite of the Eastern oyster Crassostrea virginica. J Shellfish Res 22:91-94

Elandalloussi LM, Leite RB, Rodrigues PM, Afonso R, Nunes PA, Cancela ML (2005) Effect of antiprotozoal drugs on the proliferation of the bivalve parasite Perkinsus olseni. Aquaculture 243:9-17

Faisal M, La Peyre JF, Elsayed E, Wright DC (1999) Bacitracin inhibits the oyster pathogen Perkinsus marinus in vitro and in vivo. J Aquat Anim Health 11:130-138

Flores BS, Sidall ME, Burreson EM (1996) Phyologeny of the haplosporidian (Eukaryota: Aveolata) based on small subunit ribosomal RNA sequence. J Parasitol 82:616-623

Fong D, Rodríguez R, Koo K, Sun J (1993) Small subunit ribosomal RNA gene sequence of the oyster parasite Perkinsus marinus. Mol Mar Biol Biotechnol 2:346-350

Heath RJ, Yu Y, Shapiro MA, Olson E, Rock CO (1998) Broad spectrum antimicrobial biocides target the FabI component of fatty acid synthesis. J Biol Chem 273:30316-30320
Kapoor M, Dar MJ, Surolia A, Surolia N (2001) Kinetic determinants of the interaction of enoyl-ACP reductase from Plasmodium falciparum with its substrates and inhibitors. Biochem Biophys Res Commun 289:832-837

La Peyre JF, Faisal M, Burreson EM (1993) In vitro propagation of the protozoan Perkinsus marinus, a pathogen of the Eastern oyster, Crassostrea virginica. J Eukaryot Microbiol 40:304-310

Leander BS, Keeling PJ (2004) Early evolutionary history of dinoflagellates and apicomplexans (Alveolata) as inferred from HSP90 and actin phylogenies. J Phycol 40:341-350

Levine ND (1988) The protozoan phylum Apicomplexa. CRC Press, Boca Raton, FL

Lund ED, Chu FLE, Harvey E (2004) In vitro effects of temperature and salinity on fatty acid synthesis in the oyster protozoan parasite Perkinsus marinus. J Exp Mar Biol Ecol 307:111-126

Marty Y, Delaunay F, Moal J, Samain JF (1992) Changes in the fatty acid composition of Pecten maximus (L.). J Exp Mar Biol Ecol 163:221-234

McLeod R, Muench SP, Rafferty JB, Kyle DE, and 9 others (2001) Triclosan inhibits the growth of Plasmodium falciparum and Toxoplasma gondii by inhibition of Apicomplexan Fab I. Int J Parasitol 31:109-113

Metcalfe LD, Schmitz AA (1961) The rapid preparation of fatty acid esters for gas chromatography analysis. Anal Chem 33:363-364

Orvos DR, Versteeg DJ, Inauen J, Capdevielle M, Rothenstein A, Cunningham V (2002) Aquatic toxicity of triclosan. Environ Toxicol Chem 21:1338-1349

Perozzo R, Kuo M, Sidhu ABS, Valiyaveettil JT, Bittman R, Jacobs WR Jr, Fidock DA, Sacchettini JC (2002) Structural elucidation of the specificity of the antibacterial agent triclosan for malarial enoyl acyl carrier protein reductase. J Biol Chem 277:13106-13114

Ray SM (1966a) Effects of various antibiotics on the fungus Dermocystidium marinum in thioglycollate cultures of oyster tissue. J Invertebr Pathol 8:433-438

Ray SM (1966b) Cyclohexamide: inhibition of Dermocystidium marinum in laboratory stocks of oysters. Proc Natl Shellfish Assoc 56:31-36

Reece K, Siddall E, Burreson EM, Graves JE (1997) Phylogenetic analysis of Perkinsus based on actin gene sequences. J Parasitol 83:417-423

Roberts CW, McLeod R, Rice DW, Ginger M, Chance ML, Goad LJ (2003) Fatty acid and sterol metabolism: potential antimicrobial targets in apicomplexan and trypanosomatid parasitic protozoa. Mol Biochem Parasitol 126:129-142

Siddall ME, Reece KS, Graves JE, Burreson EM (1997) 'Total evidence' refutes the inclusion of Perkinsus species in the phylum Apicomplexa. Parasitology 115:165-176

Soudant P, Chu FLE (2001) Lipid class and fatty acid composition of the protozoan parasite of oysters, Perkinsus marinus, cultivated in two different media. J Eukaryot Microbiol 48:309-319

Suguna K, Surolia A, Surolia N (2001) Structural basis for triclosan and NAD binding to enoyl-ACP reductase of Plasmodium falciparum. Biochem Biophys Res Commun 283: 224-228

Surolia N, Surolia A (2001) Triclosan offers protection against blood stages of malaria by inhibiting enoyl-ACP reductase of Plasmodium falciparum. Nat Med 7:167-172

Waller RF, Keeling PJ, Donald RGK, Striepen B and 6 others (1998) Nuclear-encoded proteins target to the plastid in Toxoplasma gondii and Plasmodium falciparum. Proc Natl Acad Sci USA 95:12352-12357 